\title{
The Effects of Cation Ratios on Root Lamella Suberization in Rice (Oryza sativa L.) with Contrasting Salt Tolerance
}

\author{
M. R. Momayezi, ${ }^{1}$ A. R. Zaharah, ${ }^{2}$ and M. M. Hanafi ${ }^{2}$ \\ ${ }^{1}$ Agronomy Department, Faculty of Agriculture, Varamin-Pishva Branch, Islamic Azad University, Varamin, Iran \\ ${ }^{2}$ Land Resource Management Department, Universiti Putra Malaysia, 43400 Serdang, Selangor, Malaysia
}

Correspondence should be addressed to M. R. Momayezi, momayeziir@gmail.com

Received 29 September 2011; Accepted 14 February 2012

Academic Editor: Patrick J. Tranel

Copyright ( 2012 M. R. Momayezi et al. This is an open access article distributed under the Creative Commons Attribution License, which permits unrestricted use, distribution, and reproduction in any medium, provided the original work is properly cited.

\begin{abstract}
Rice is an important produced cereal in the world. We evaluated the effect of salt compositions including $\mathrm{NaCl}_{\text {and }} \mathrm{Na}_{2} \mathrm{SO}_{4}$ on suberin lamellae as a major barrier to radial ion and water movements in two rice genotypes representing contrasting salt tolerance levels under salinity stress. Two rice genotypes, Fajr as salt tolerant and Khazar as salt sensitive, were transplanted in sand culture under glasshouse condition. Rice seedlings were treated with five salt compositions including $\mathrm{NaCl}_{1} \mathrm{Na}_{2} \mathrm{SO}_{4}, 1: 1,1: 2$, and $2: 1$ molar ratios for 40 days. It was proven that suberin lamellae in endodermis of root cell wall were thickened with $\mathrm{Na}_{2} \mathrm{SO}_{4}$ treatment. The results demonstrated that the number of passage cells was higher in Fajr genotype than that in Khazar genotype under saline condition. Calcium concentration in root tissue decreased as the $\mathrm{SO}_{4}{ }^{2-}$ concentration in root media increased. It can be concluded that Fajr genotype is able to keep some passage cells open to maintain $\mathrm{Ca}^{2+}$ uptake. The $\mathrm{Ca}^{2+} / \mathrm{Na}^{+}$ratio in shoot tissue can be also a reliable index for the early recognition of salt stress in these rice genotypes.
\end{abstract}

\section{Introduction}

When plants are exposed to the environmental conditions such as salinity stress, they have to overcome drought. It is necessary to prevent water and nutrient that were taken up by the roots from leaking out of the root tissues. Three parallel pathways of water uptake from the soil solution into the central cylinder of the root are known: (1) the apoplastic pathway around protoplasts, (2) the symplastic pathway through plasmodesmata, and (3) the transcellular pathway with the water molecules moving from one living cell to the next by crossing two plasma membranes and part of the apoplast at each cell layer [1]. Water and dissolved solutes movements through the cell wall or apoplast are prevented by the Casparian band. If these movements are blocked in the apoplast, these materials (water and dissolved solutes) must pass through the plasma membrane and be transported in the protoplast via the plasmodesmata.

The response of plants to environmental conditions, such as drought, salt stress, or oxygen deficiency, is usually associated with suberin deposition in apoplastic pathway.
The formation of suberin, as an extracellular biopolymer can be an effective strategy [2]. Suberized walls in the endodermis are known as the major barriers to radial ion and water movements in plant roots [3].

The architecture of roots including their anatomy and morphology is affected by growth conditions $[4,5]$. This attribute may allow some flexibility in response of rice to water shortage according to the demand from the shoot tissue under saline conditions [6].

The structural changes in root cell wall are known as mechanical impedance to protecting the root from water loss and/or leakage of solutes. This may play an important role in osmotic adjustment [3]. The studies on radial apoplastic water transport of roots revealed that plants adjust the degree of suberization in their tissues in response to environmental stimuli and regulating the apoplastic transport of water and solutes $[2,7,8]$.

Plants establish suberin lamellae at the inner side surfaces of either epidermal or endodermal cell walls with the exception of the passage cells [8]. Apoplastic barriers in rice roots have been reported in both the exodermal and endodermal 
cell walls $[9,10]$. It has been revealed that the main resistance for radial water flow in rice roots is located in the endodermis $[10,11]$.

A reduction in nutrient uptake $(\mathrm{K}, \mathrm{Ca})$ and toxic ions effects of excess $\mathrm{Na}^{+}$and $\mathrm{Cl}^{-}$uptake are two effects of salinity on crops. The nutrients available, competitive uptake, and transport or compartmentalizing within plant tissue were affected by many factors in soil-plant environment. The ascending salinity levels significantly reduced potassium $\left(\mathrm{K}^{+}\right)$and calcium $\left(\mathrm{Ca}^{2+}\right)$ accumulation in shoots, while the concentration of sodium $\left(\mathrm{Na}^{+}\right)$was increased [12]. High concentration of $\mathrm{Na}^{+}$in soil solution or rhizosphere may reduce nutrient uptake and the $\mathrm{Ca}^{2+} / \mathrm{Na}^{+}$and $\mathrm{K}^{+} / \mathrm{Na}^{+}$ratios within plant tissues. It means that there is a complex antagonistic effect between salinity in rhizosphere and nutrient uptake by plants. $\mathrm{Na}^{+}$as a major cation in saline conditions reduces $\mathrm{K}^{+}$and $\mathrm{Ca}^{2+}$ uptake [13].

The maintenance of adequate levels of nutrient elements particularly $\mathrm{K}^{+}$and $\mathrm{Ca}^{2+}$ can be a defense mechanism against the salinity stress [13]. The $\mathrm{Na}^{+}$salinity with $\mathrm{Cl}^{-}$or $\mathrm{SO}_{4}{ }^{2-}$ dominance has a different effect on nutrient uptake, and the response of plant species to each of these salinising systems is different. For instance, the $\mathrm{K}^{+}$content of chickpea and pea shoot was greater in the $\mathrm{SO}_{4}{ }^{2-}$ system than in the $\mathrm{Cl}^{-}$ system. In contrast, $\mathrm{Ca}^{2+}$ uptake was greater from a $\mathrm{Cl}^{-}$dominated solution compared to $\mathrm{SO}_{4}{ }^{2-}$ system [14-16]. The balance of nutrients $\left(\mathrm{K}^{+}, \mathrm{Ca}^{2+}\right.$, and $\left.\mathrm{Mg}^{2+}\right)$ is compulsory for the biochemical components or cytosolic enzymes activities [17] or cell membrane potential rectification $[18,19]$.

There are few works to understand the deposition and function of suberin lamella in response to salt stress in rice [20]. However, there is no available knowledge to show the effects of different salt compositions on suberin lamellae in root cell walls. Therefore, it is expected that the suberin lamellae as mechanical impedance can play an important role to withstand salinity stress and could be a useful subject for the development of increased salinity resistance. On the other hand, nutrients uptake, especially $\mathrm{Ca}^{2+}$, can be controlled by suberin development in cell wall of roots under salinity conditions. Many studies have been focused on the responses of rice genotypes to $\mathrm{NaCl}$ salinity stress [21, 22]. It is assumed that salt compositions might play a role in plant response to salinity stress, but direct evidence is generally lacking. Only a few studies have compared the different salt mixtures [23-25]. Therefore, this study focused on the effects of different salt compositions on suberin development in the roots and as mechanical impedance for mineral nutrient uptake as in two rice genotypes representing contrasting levels of salt tolerance under the salinity stress.

\section{Materials and Method}

The experiment was conducted in the greenhouse at Universiti Putra Malaysia (UPM) from December 2008 to February 2009. Ten rice seedlings of Fajr and Khazar genotypes as salt tolerant and sensitive, respectively, were transferred to pots that contained $12 \mathrm{~kg}$ acid-washed sand. The pots were placed in the glasshouse in a randomized complete block design (RCBD) in 3 replications at ambient conditions. Air temperature ranged from 30 to $34^{\circ} \mathrm{C}$ during the day and from 26 to $28^{\circ} \mathrm{C}$ during the night. The pots were flooded with distilled water for 3 days after transplanting, after that the rice seedlings were grown using half strength Hoagland's and saline solutions. Five uniform seedlings were kept in each pot after salt treatment. Salt treatments of $\mathrm{NaCl}, \mathrm{Na}_{2} \mathrm{SO}_{4}$ and their mixtures (1:1,2:1, and $1: 2$ molar concentrations) were dissolved in nutrient solution at EC of $7 \mathrm{dS} \mathrm{m}^{-1}$ for 40 days. Electrical conductivity of nutrient solution as control was maintained at $1 \mathrm{dS} \mathrm{m}^{-1}$. Nutrient solution was renewed every week. The water level was maintained at $5 \mathrm{~cm}$ above the sand surface with distilled water to each pot every day. Forty days after salt treatment, rice seedlings were harvested for the evaluation of the presence of suberin in the lamellae of cell walls of the primary roots and root characteristics. Subsequently, water content and mineral nutrient concentrations were measured in root and shoot tissues, separately.

The clean roots were scanned by WINRHIZO system (Soil Chemistry lab, Land Resource Management Department, UPM). The freehand cross-sections were made at 50$100 \mathrm{~mm}$ from the root tips. The average lengths of rice roots (lateral root) were $25 \mathrm{~cm}$. They were stained with Sudan Black B [26]. The thin sections were stained by saturated solution of Sudan Black B (dissolved in 70\% ethyl alcohol) for 1 hour at room temperature and washed briefly in water and mounted in $75 \%$ glycerol $(\mathrm{v} / \mathrm{v})$. Sections were viewed under a light microscope (Olympus bx51, Olympus and Melville, NY, USA).

Plant materials (shoot and root separately) were dried in a forced-air oven $\left(70-75^{\circ} \mathrm{C}\right)$ for 48 hours. Dry and fresh weight and water content were calculated. Mineral nutrient analysis $\left(\mathrm{Ca}^{2+}, \mathrm{Mg}^{2+}, \mathrm{K}^{+}\right.$, and $\left.\mathrm{Na}^{+}\right)$in root and shoot tissues, was performed the dry ashing method as described by Sahrawat et al. [27]. Five hundred $\mathrm{mg}$ of samples (root or shoot part) were burned to ash by using a muffle furnace for 6 hours at $550^{\circ} \mathrm{C}$. Concentrated $\mathrm{HCl}$ and $\mathrm{HNO}_{3}(20 \%)$ were added to the ash and heated for 1 hour. The mixture was decanted into $25 \mathrm{~mL}$ volumetric flask and made to volume with distilled water. The solution was analyzed for $\mathrm{K}^{+}, \mathrm{Ca}^{2+}$, $\mathrm{Mg}^{2+}$, and $\mathrm{Na}^{+}$by the inductively coupled argon-plasma emission spectrometry (ICP trace analyzer; Land Resource Management Department, UPM).

2.1. Statistical Analysis. Collected data were subjected to analysis of variance (ANOVA) using SAS program (SAS Institute Inc, 1998) to compute genotypic (G) and salt composition effects (SC) and their interactions. ANOVA was also done, and Tukey's Studentized procedure $(P \leq 0.05)$ was used to detect significant differences.

\section{Results}

Agronomic Parameters. Salinity stress significantly $(P \leq$ 0.05 ) affected the agronomic parameters. The main effects of genotypes and salt compositions were significant for most of agronomic parameters. However, the interactive effect between rice genotype and salt composition was not significant (Table 1). The data analysis within rice genotypes 
TABLE 1: Analysis of variance (ANOVA) of agronomic parameters after 40-day salinity stress. The results represent F-values at 5\% level of probability.

\begin{tabular}{|c|c|c|c|c|c|c|c|c|c|}
\hline \multirow{2}{*}{ Independent variable } & \multicolumn{3}{|c|}{ Root characteristics } & \multirow[b]{2}{*}{ Tips } & \multirow{2}{*}{ Root-shoot ratio } & \multicolumn{2}{|c|}{ Dry biomass (g) } & \multicolumn{2}{|c|}{ Water content $(\%)$} \\
\hline & Length $(\mathrm{cm})$ & Surface area $\left(\mathrm{cm}^{2}\right)$ & Volume $\left(\mathrm{cm}^{3}\right)$ & & & Root & Shoot & Root & Shoot \\
\hline Rice genotype & $34.1^{*}$ & $29.1^{*}$ & $19.5^{*}$ & $33.9^{*}$ & $17.8^{*}$ & $44.7^{*}$ & $42.6^{*}$ & $4.8^{*}$ & $1.8 \mathrm{~ns}$ \\
\hline Salt composition & $3.6^{*}$ & $2.0 \mathrm{~ns}$ & $1.3 \mathrm{~ns}$ & $14.4^{*}$ & $2.9^{*}$ & $5.3^{*}$ & $6.7^{*}$ & $1.1 \mathrm{~ns}$ & $6.3^{*}$ \\
\hline Interactive effect & $0.6 \mathrm{~ns}$ & $1.2 \mathrm{~ns}$ & $1.3 \mathrm{~ns}$ & $1.5 \mathrm{~ns}$ & $0.3 \mathrm{~ns}$ & $0.8 \mathrm{~ns}$ & $2.4 \mathrm{~ns}$ & $0.7 \mathrm{~ns}$ & $1.3 \mathrm{~ns}$ \\
\hline
\end{tabular}

ns: not significant; ${ }^{*}$ : significant at 5

TABle 2: Agronomic parameters of rice genotypes exposed to different salt compositions. The same letter in each column is not significant at $5 \%$ level of probability.

\begin{tabular}{|c|c|c|c|c|c|c|c|c|}
\hline \multirow{2}{*}{ Rice genotype } & \multicolumn{4}{|c|}{ Root characteristics } & \multirow{2}{*}{ Root-shoot ratio } & \multicolumn{2}{|c|}{ Dry biomass (g) } & \multirow{2}{*}{$\begin{array}{l}\text { Water content of } \\
\quad \operatorname{root}(\%)\end{array}$} \\
\hline & $\begin{array}{l}\text { Length } \\
(\mathrm{cm})\end{array}$ & $\begin{array}{c}\text { Surface } \\
\text { area }\left(\mathrm{cm}^{2}\right)\end{array}$ & $\begin{array}{c}\text { Volume } \\
\left(\mathrm{cm}^{3}\right)\end{array}$ & Tips & & Root & Shoot & \\
\hline Fajr & $164.7 \mathrm{~A}$ & $21.4 \mathrm{~A}$ & $0.23 \mathrm{~A}$ & $1187.7 \mathrm{~A}$ & $5.3 \mathrm{~A}$ & $10.9 \mathrm{~A}$ & $56.0 \mathrm{~A}$ & $92.6 \mathrm{~A}$ \\
\hline Khazar & $64.3 \mathrm{~B}$ & $6.4 \mathrm{~B}$ & $0.05 \mathrm{~B}$ & $398.7 \mathrm{~B}$ & $2.7 \mathrm{~B}$ & $4.7 \mathrm{~B}$ & $27.5 B$ & $91.4 \mathrm{~B}$ \\
\hline
\end{tabular}

demonstrated that Fajr genotype, as salt tolerant, had the highest values of agronomic parameters including root characteristics, root-shoot ratio, dry biomass, and water content of roots (Table 2 ). Salinity stress significantly decreased root characteristics and root-shoot ratio compared to control. In accordance with the effect of different salt compositions on root growth, single salts $\left(\mathrm{NaCl}\right.$ and $\left.\mathrm{Na}_{2} \mathrm{SO}_{4}\right)$ decreased root length more than mixed salt treatments $(1: 1,1: 2$, and 2:1 molar ratios). Nevertheless, root tips showed no significant changes at different salt composition treatments. The highest and the lowest water content of shoot tissue were recorded for $\mathrm{NaCl}$ and 1:2 molar ratios, respectively. On the other hand, the lowest and the highest dry biomass were observed at $1: 1$ molar ratio and $\mathrm{NaCl}$ treatments, respectively (Table 3 ).

Suberin Lamellae. Root dissections showed that there were striking differences in color density of endodermal cell wall (Figure 1). Passage cells were visible for Fajr genotype at control and EC of $7 \mathrm{dS} \mathrm{m}^{-1}$; however, there were a few passage cells in the endodermal cell wall of Khazar genotype at the same treatment.

Data of the thickness of suberin lamellae in endodermis showed that suberin deposition was significantly $(P \leq 0.05)$ affected by salinity stress. There was an interactive effect between genotype and salt composition. Rice genotypes demonstrated different responses to salinity stress (Figure 2). Salt composition significantly affected the thickness of suberin lamellae but with substantial variability between rice genotypes ranging from 19.6 to $5.1 \mu \mathrm{m}$ and 12.7 to $3.9 \mu \mathrm{m}$ for Khazar and Fajr genotypes, respectively. The thickest and the thinnest of suberized lamellae were recorded for both Fajr (salt tolerant) and Khazar genotypes at $\mathrm{Na}_{2} \mathrm{SO}_{4}$ and 2:1 salt compositions, respectively.The effect of salt compositions on the thickness of suberized lamellae was significantly $(P \leq 0.05)$ recorded when the analysis was done within salt compositions. The thickest of suberized lamellae were recorded at $\mathrm{Na}_{2} \mathrm{SO}_{4}$ treatments, and the thinnest of suberized lamellae were observed at 2:1 molar ratio
(Figure 3). However, no significant differences in suberized lamella thickness were observed between mixed salts $(1: 1$, $1: 2$, and $2: 1$ molar ratios).

In accordance with the effect of salt concentration on suberized lamellae, rice genotypes with different salt resistances demonstrated the different responses to salt levels. Reduction of the thickness of suberized lamellae was observed for Khazar genotype as salt sensitive when salt concentration increased. However Fajr genotype as salt tolerant showed an increase in the thickness of suberized lamellae by increasing salt concentration, regardless of salt composition (Figure 4).

Mineral Nutrients Status. The data from the mineral nutrients concentrations showed a significant difference between control and salt compositions. Rice genotypes maintained the mineral nutrient ratios in root tissue. An interactive effect between salt composition and rice genotypes was not significant. The data analysis within control and different salt compositions showed that $\mathrm{Na}^{+}$concentrations increased in root and shoot tissues. The highest sodium concentration in root tissue (by about $11 \mu \mathrm{g} \cdot \mathrm{g}^{-1} \mathrm{DW}$ ) and shoot tissue (by about $118 \mu \mathrm{g} \cdot \mathrm{g}^{-1} \mathrm{DW}$ ) were recorded for $2: 1$ ratio (Figures 5 and 6). On the other hand, the lowest sodium concentrations in root tissue (by about $4 \mu \mathrm{g} \cdot \mathrm{g}^{-1} \mathrm{DW}$ ) and shoot tissue (by about $28 \mu \mathrm{g} \cdot \mathrm{g}^{-1} \mathrm{DW}$ ) were observed for $\mathrm{Na}_{2} \mathrm{SO}_{4}$. As shown in Figures 5 and 6 , potassium uptake was inhibited by salinity stress especially at $\mathrm{NaCl}$ and $\mathrm{Na}_{2} \mathrm{SO}_{4}$ treatments. Potassium concentration in root and shoot tissues showed a decrease at $\mathrm{NaCl}$ and $\mathrm{Na}_{2} \mathrm{SO}_{4}$ treatments; however, an upward tendency was observed at different salt ratios $(1: 1,1: 2$ and $2: 1$ ratios). The highest and the lowest calcium concentration in root tissue were at $2: 1$ ratio and $\mathrm{Na}_{2} \mathrm{SO}_{4}$ treatments, respectively (Figure 5). Therefore, it seems there was an antagonistic effect between $\mathrm{Ca}^{2+}$ uptake and $\mathrm{SO}_{4}{ }^{2-}$ concentration in the root medium. Salinity stress decreased $\mathrm{K}^{+}, \mathrm{Ca}^{2+}$, and $\mathrm{Mg}^{2+}$ concentration but increased $\mathrm{Na}^{+}$concentration in shoot tissue. The assessment of mineral nutrient ratios across the two rice genotypes also revealed 
Table 3: The salt composition effect on root length, root tips, root-shoot ratio, and water content of shoot. The same letter in each column is not significant at $5 \%$ level of probability.

\begin{tabular}{|c|c|c|c|c|c|c|}
\hline \multirow{2}{*}{ Salt composition } & \multicolumn{2}{|c|}{ Root characteristics } & \multirow{2}{*}{ Root-shoot ratio } & \multicolumn{2}{|c|}{ Dry biomass (g) } & \multirow{2}{*}{$\begin{array}{c}\text { Water content of } \\
\text { shoot }(\%)\end{array}$} \\
\hline & Length $(\mathrm{cm})$ & Tips & & Root & Shoot & \\
\hline Control & $192.0 \mathrm{~A}$ & $2053.0 \mathrm{~A}$ & $5.8 \mathrm{~A}$ & $7.5 \mathrm{AB}$ & $49.3 \mathrm{AB}$ & $86.1 \mathrm{AB}$ \\
\hline $\mathrm{NaCl}$ & $78.25 \mathrm{~B}$ & 470.7B & $2.1 \mathrm{~B}$ & $12.5 \mathrm{~A}$ & $62.7 \mathrm{~A}$ & $87.4 \mathrm{~A}$ \\
\hline $\mathrm{Na}_{2} \mathrm{SO}_{4}$ & $98.4 \mathrm{~B}$ & $780.2 \mathrm{~B}$ & $3.1 \mathrm{AB}$ & $8.2 \mathrm{AB}$ & $40.2 \mathrm{ABC}$ & $83.4 \mathrm{BC}$ \\
\hline $1: 1$ & 103.7AB & $426.8 \mathrm{~B}$ & $4.4 \mathrm{AB}$ & $4.8 \mathrm{~B}$ & $21.0 \mathrm{C}$ & 84.0ABC \\
\hline $1: 2$ & $115.1 \mathrm{AB}$ & $568.7 \mathrm{~B}$ & $4.3 \mathrm{AB}$ & $8.0 \mathrm{AB}$ & $39.8 \mathrm{ABC}$ & $81.8 \mathrm{C}$ \\
\hline $2: 1$ & $99.6 \mathrm{AB}$ & $460.0 \mathrm{~B}$ & $4.3 \mathrm{AB}$ & $5.8 \mathrm{~B}$ & $37.5 \mathrm{BC}$ & $83.4 \mathrm{BC}$ \\
\hline
\end{tabular}
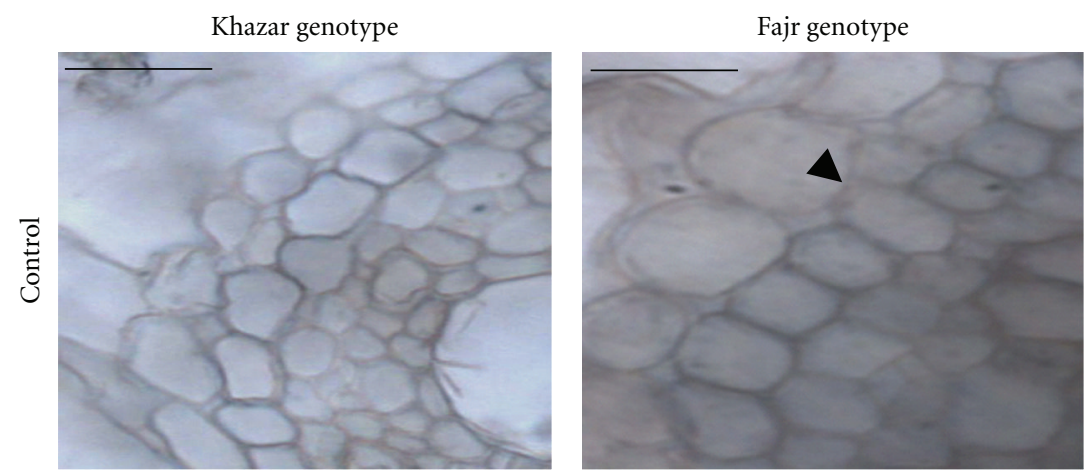

(a)
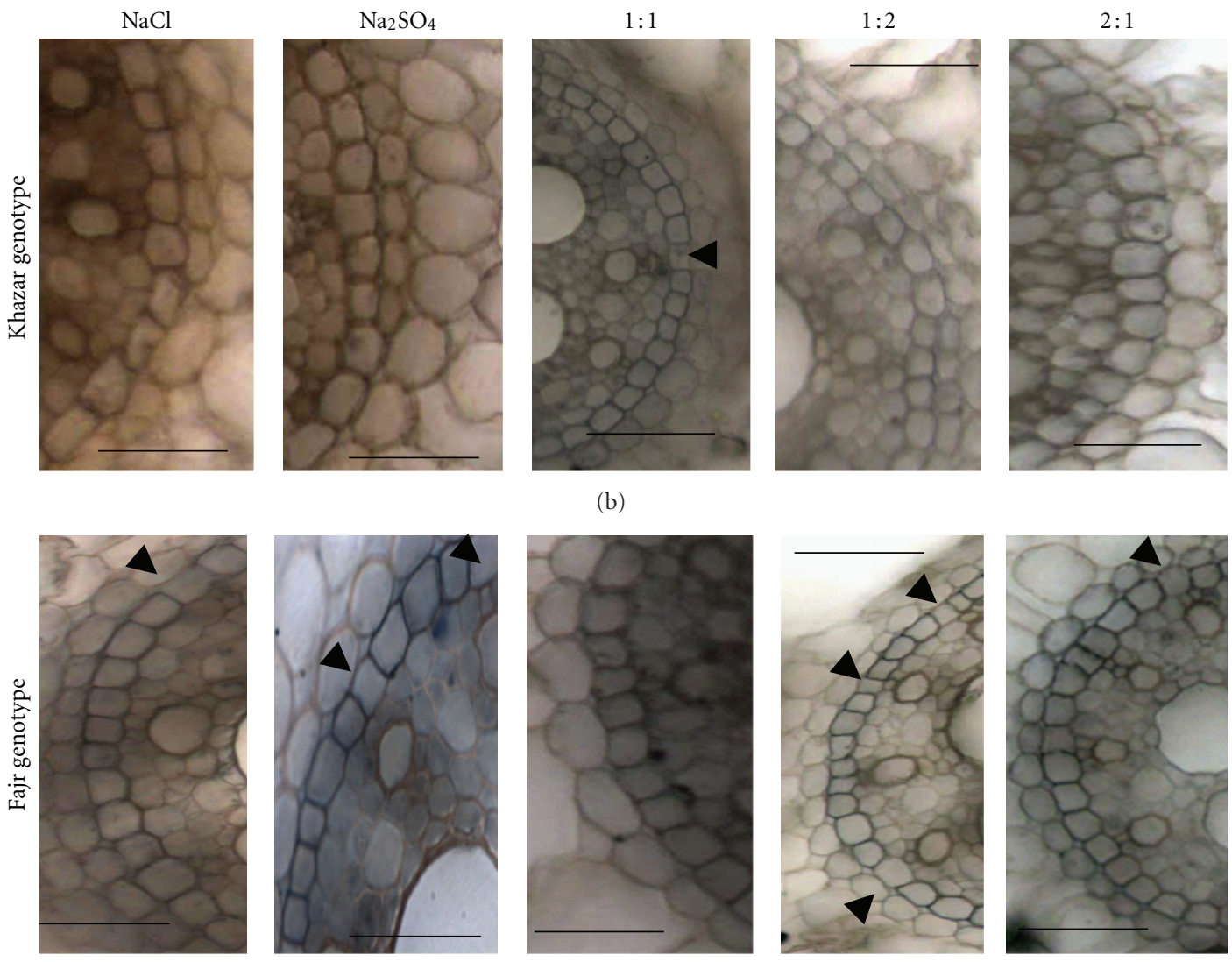

(c)

FIGURE 1: Deposition of suberin lamellae in endodermis of two rice genotypes roots. Black arrowheads show passage cells. Bar $=100 \mu \mathrm{m}$. 


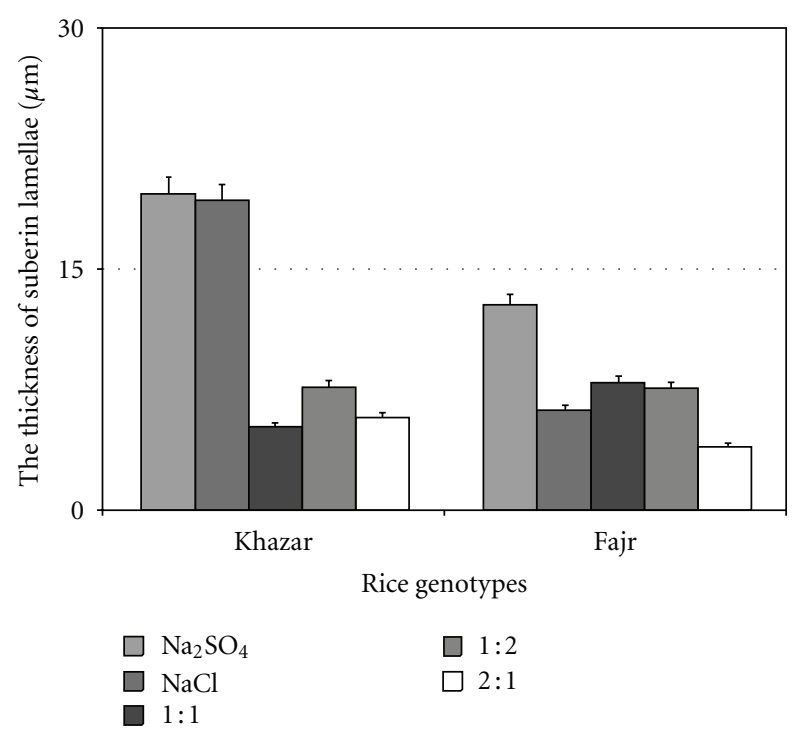

Figure 2: The interactive effect between salt composition and rice genotypes on the thickness of suberin lamellae at endodermis. Vertical bar represents + SE.

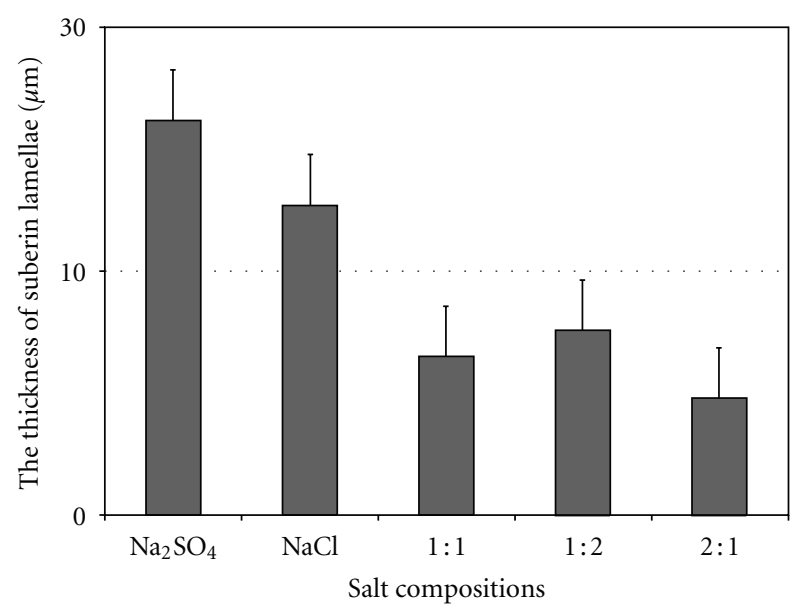

FIgURE 3: The effect of salt composition on the thickness of suberin lamellae at endodermis. Vertical bar represents + SE.

that Fajr genotype had the highest $\mathrm{Ca}^{2+} / \mathrm{Na}^{+}$ratio in both root (by about 0.3) and shoot (by about 1.5) tissues. Khazar genotype showed the lowest ratios of mineral nutrients (Figure 7).

\section{Discussion}

Dry matter biomass production and partitioning between different plant tissues were significantly altered by salt stress. The decrease in shoot biomass was greater than that inroot biomass due to salt stress. It can be suggested that growth of rice roots is less sensitive to salinity than shoot growth. The response of plant to high salinity is a decrease in the rate of shoot growth with the consequence of reducing whole-plant leaf area [28]. Salinity reduced shoot growth more than root growth. This result was similar to that of

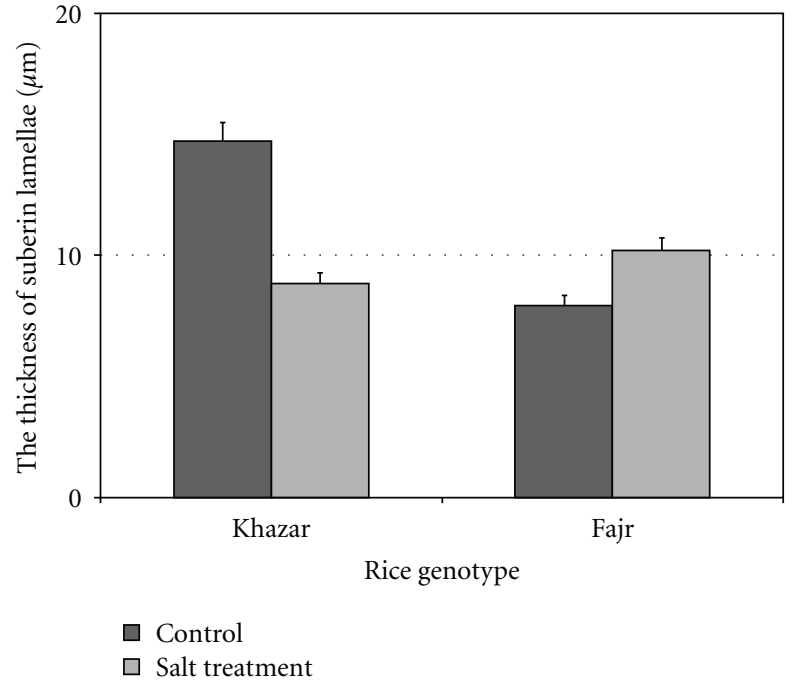

FIgURE 4: The interactive effect between salt concentration and rice genotypes on the thickness of suberin lamellae at endodermis. Vertical bar represents + SE.

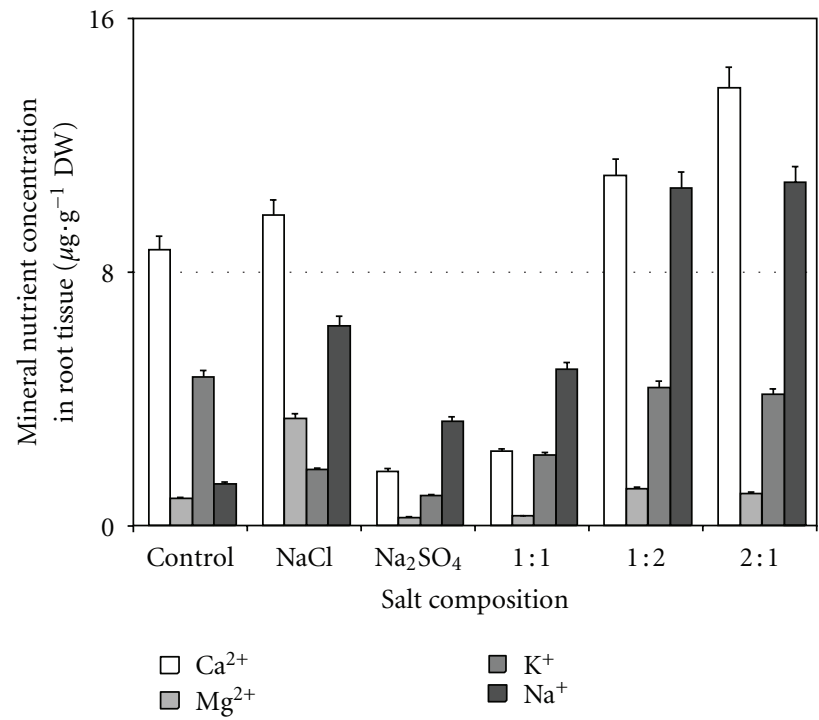

FIGURE 5: The comparison of mineral nutrients accumulation in root tissue between control and EC7 at different salt composition. Vertical bar represented + SE.

the study of Munns [29], which showed that root-shoot ratio increased by salt stress. The results revealed that Fajr genotype as salt tolerant demonstrated high root-shoot ratio and high water content of root tissue. It is seen that this genotype was able to adapt to this condition because it had the highest water content percentage (Tables 2 and 3). Consequently, this genotype was able to take up water from the root media under saline condition. Suberin deposition was also increased in endodermal cells of Fajr genotype by increasing salt concentration. However, Khazar genotype as a salt sensitive showed a reduction of suberin deposition at $7 \mathrm{dS} \mathrm{m}{ }^{-1}$ compared to control (Figure 4). Suberin lamellae 


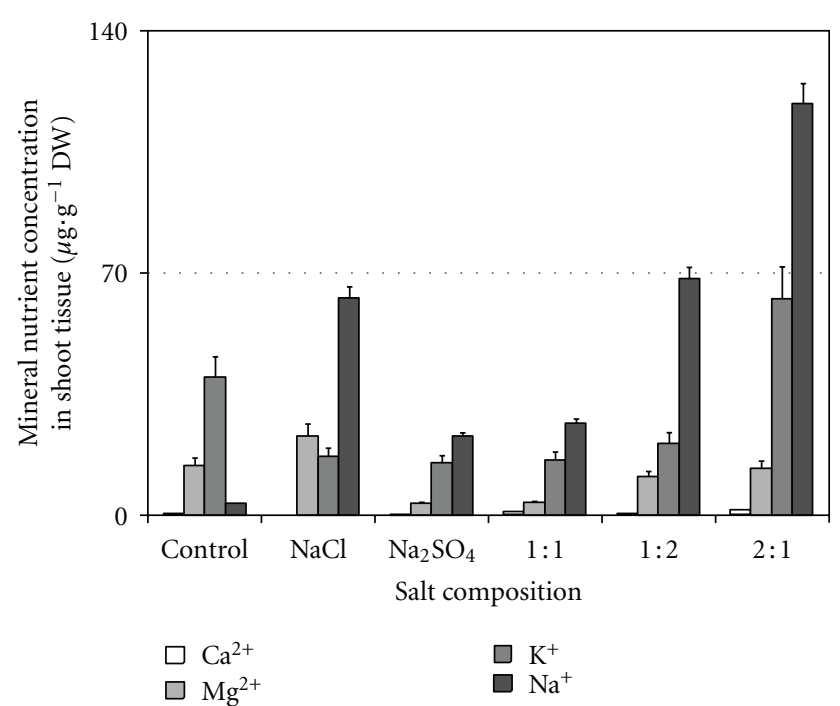

Figure 6: The comparison of mineral nutrients accumulation in shoot tissue between control and EC7 at different salt composition. Vertical bar represents + SE.

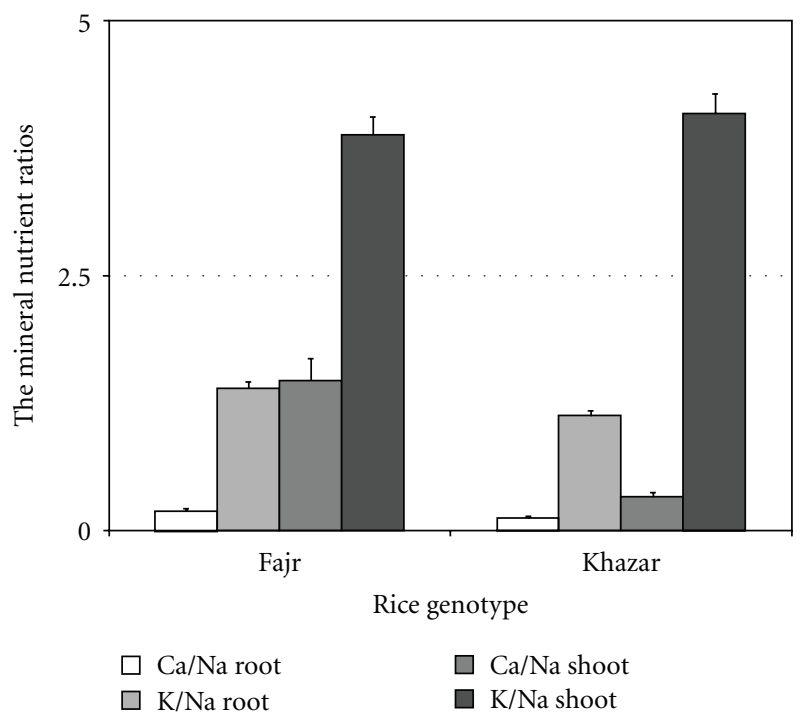

FIgURE 7: The mineral nutrient ratios of rice seedlings including root and shoot tissue. Vertical bar represents + SE.

as the major barriers can control radial water movement resulting in osmotic adjustment [3]. The results of this study proved that suberization was extended to endodermal cells of Fajr genotype more than Khazar genotype. This mechanism can be defined as mechanical impedance against salt stress (Table 2 and Figure 4). This result was confirmed by the study of Krishnamurthy et al. [20].

The findings of this study show that $\mathrm{Ca}^{2+}$ concentration in root tissue decreases by increasing $\mathrm{SO}_{4}{ }^{2-}$ concentration in root media (Figure 5). It appears that there is an antagonistic effect between high $\mathrm{SO}_{4}{ }^{2-}$ concentration and $\mathrm{Ca}^{2+}$ uptake. Besides, it has been indicated that $\mathrm{Ca}^{2+}$ in biological systems plays a signaling role [33]. It has also been reported that high $\mathrm{Na}^{+}$concentration in maize rhizosphere induced an increase in cytosolic $\mathrm{Ca}^{2+}$ that was taken up through the apoplastic pathway and intracellular compartments [30]. Furthermore, it proved that the change in salt composition affects mineral uptake and their transport from root to shoot tissues. The $\mathrm{Ca}^{2+} / \mathrm{Na}^{+}$instead of $\mathrm{K}^{+} / \mathrm{Na}^{+}$ratio in shoot tissue is a reliable index to explain salt tolerance in rice genotypes. Fajr as salt-tolerant and Khazar as salt-sensitive genotypes showed the highest and the lowest $\mathrm{Ca}^{2+} / \mathrm{Na}^{+}$ratio, respectively (Figure 7). This result confirms that calcium uptake decreased with salinity in Khazar genotype (salt sensitive) while it remained at constant levels in Fajr genotype (salt tolerant) [31].

High salt concentrations induce suberization in endodermis and suberin lamellae are also identified an apoplastic barrier. Some studies implicate an additional bypass pathway for $\mathrm{Na}^{+}$and $\mathrm{K}^{+}$uptake at high salt concentrations [32]. However, there is only an apoplastic bypass pathway for $\mathrm{Ca}^{2+}$ [33]. On the other hand, it is also noted that suberin lamellae in Khazar genotype (salt sensitive) are thicker than in Fajr genotype at $\mathrm{Na}_{2} \mathrm{SO}_{4}$ treatment (Figure 2).

These results obtained implicate a relationship between the uptake of nutrient elements and apoplastic barrier such as suberin lamellae in endodermis. When salt concentration increases up to EC of $7 \mathrm{dS} \mathrm{m}^{-1}$ with $\mathrm{Na}_{2} \mathrm{SO}_{4}$ treatment, the thickened suberin lamellae (Figure 3 ) are accompanied by a decrease in $\mathrm{Ca}^{2+}$ uptake (Figure 5). It can be interpreted that the apoplastic pathway is blocked by suberin deposition as the salt concentration increases and consequently $\mathrm{Ca}^{2+}$ uptake through apoplastic pathway is limited. In this case, salt composition especially $\mathrm{Na}_{2} \mathrm{SO}_{4}$ treatment intensifies that mechanism. Therefore, the radial transport of $\mathrm{Ca}^{2+}$ can only be controlled by the number of passage cells in root tissues. As shown in Figure 1, the number of passage cells increase more in Fajr genotype than in Khazar genotype. Fajr genotype (salt tolerant) is able to keep some passage cells without suberin lamellae to maintain plasma membrane permeability of endodermis, and the $\mathrm{Ca}^{2+} / \mathrm{Na}^{+}$ratio in Fajr genotype is more than in Khazar genotype. It can also be concluded that Fajr genotype with passage cells in its root tissue has the highest concentration of $\mathrm{Ca}^{2+}$ in its shoot tissues (Figure 7).

The least $\mathrm{Ca}^{2+}$ uptake by rice seedlings exposed to $\mathrm{Na}_{2} \mathrm{SO}_{4}$ salt stress also proves that $\mathrm{Ca}^{2+}$ concentration in root tissue decreased by increasing $\mathrm{SO}_{4}{ }^{2-}$ concentration in root media (Figure 5). It suggests that there is an antagonistic effect between high $\mathrm{SO}_{4}{ }^{2-}$ concentration and $\mathrm{Ca}^{2+}$ uptake.

\section{Conclusion}

We report for the first time that salt compositions differently affected suberin deposition in endodermis. The deposition of suberin in cell wall increased when single salts were applied for salt treatment compared to mixed salts. The most study of salt effects on suberization have been focused on $\mathrm{NaCl}$ effects. Because of the different compositions of soil solution at natural conditions, it seems that the response of rice genotypes to salinity under field conditions may be different 
under greenhouse conditions. The results from this study implicate a significant relationship between the uptake of nutrient elements and apoplastic barrier such as suberin lamellae in endodermis.

The results of this study show that there is a relationship between suberin depositions in endodermic cell wall and the number of passage cells in rice salt-tolerant genotypes. Of course, this challenge needs to be assessed by more studies.

\section{References}

[1] L. Schreiber, R. Franke, K. D. Hartmann, K. Ranathunge, and E. Steudle, "The chemical composition of suberin in apoplastic barriers affects radial hydraulic conductivity differently in the roots of rice (Oryza sativa L. cv. IR64) and corn (Zea mays L. cv. Helix)," Journal of Experimental Botany, vol. 56, no. 415, pp. 1427-1436, 2005.

[2] R. Franke and L. Schreiber, "Suberin-a biopolyester forming apoplastic plant interfaces," Current Opinion in Plant Biology, vol. 10, no. 3, pp. 252-259, 2007.

[3] D. H. Reinhardt and T. L. Rost, "Salinity accelerates endodermal development and induces an exodermis in cotton seedling roots," Environmental and Experimental Botany, vol. 35, no. 4, pp. 563-574, 1995.

[4] E. Steudle and C. A. Peterson, "How does water get through roots?" Journal of Experimental Botany, vol. 49, no. 322, pp. 775-788, 1998.

[5] E. Steudle, "Water uptake by roots: effects of water deficit," Journal of Experimental Botany, vol. 51, no. 350, pp. 15311542, 2000.

[6] K. Ranathunge, L. Kotula, E. Steudle, and R. Lafitte, "Water permeability and reflection coefficient of the outer part of young rice roots are differently affected by closure of water channels (aquaporins) or blockage of apoplastic pores," Journal of Experimental Botany, vol. 55, no. 396, pp. 433-447, 2004.

[7] H. M. Zimmermann, K. Hartmann, L. Schreiber, and E. Steudle, "Chemical composition of apoplastic transport barriers in relation to radial hydraulic conductivity of corn roots (Zea mays L.)," Planta, vol. 210, no. 2, pp. 302-311, 2000.

[8] E. Hose, D. T. Clarkson, E. Steudle, L. Schreiber, and W. Hartung, "The exodermis: a variable apoplastic barrier," Journal of Experimental Botany, vol. 52, no. 365, pp. 2245-2264, 2001.

[9] L. H. Clark and W. H. Harris, "Observation on the root anatomy of rice (Oryza sativa L.)," American Journal of Botany, vol. 68 , no. 2, pp. 154-161, 1981.

[10] K. Ranathunge, E. Steudle, and R. Lafitte, "Blockage of apoplastic bypass-flow of water in rice roots by insoluble salt precipitates analogous to a Pfeffer cell," Plant, Cell and Environment, vol. 28, no. 2, pp. 121-133, 2005.

[11] N. Miyamoto, E. Steudle, T. Hirasawa, and R. Lafitte, "Hydraulic conductivity of rice roots," Journal of Experimental Botany, vol. 52, no. 362, pp. 1835-1846, 2001.

[12] N. Iqbal, M. Y. Ashraf, F. Javed, V. Martinez, and K. Ahmad, "Nitrate reduction and nutrient accumulation in wheat grown in soil salinized with four different salts," Journal of Plant Nutrition, vol. 29, no. 3, pp. 409-421, 2006.

[13] S. R. Grattan and C. M. Grieve, "Salinity-mineral nutrient relations in horticultural crops," Scientia Horticulturae, vol. 78, no. 1-4, pp. 127-157, 1998.

[14] H. R. Manchanda and S. K. Sharma, "Tolerance of chloride and sulfate salinity in chickpea (Cicer arietinum)," The Journal of Agricultural Science, vol. 113, no. 03, pp. 407-410, 1989.
[15] H. R. Manchanda, S. K. Sharma, and R. P. Mor, "Relative tolerance of pulses for chloride and sulfate salinity," Indian Journal of Agricultural Science, vol. 61, pp. 20-26, 1991.

[16] R. P. Mor and H. R. Manchanda, "Influence of phosphorus on the tolerance of table pea to chloride and sulfate salinity in a sandy soil," Arid Soil Research \& Rehabilitation, vol. 6, no. 1, pp. 41-52, 1992.

[17] A. R. Memon, M. Saccomani, and A. D. M. Glass, "Efficiency of potassium utilization by barley (Hordeum vulgare) varieties the role of subcellular compartmentation," Journal of Experimental Botany, vol. 36, no. 12, pp. 1860-1876, 1985.

[18] E. A. C. MacRobbie, "Function of ion transport in plant cells and tissues," MTP International Review of Science Biochemistry Series, vol. 13, pp. 211-247, 1977.

[19] R. A. Leigh, "Potassium homeostasis and membrane transport," Journal of Plant Nutrition and Soil Science, vol. 164, no. 2, pp. 193-198, 2001.

[20] P. Krishnamurthy, K. Ranathunge, R. Franke, H. S. Prakash, L. Schreiber, and M. K. Mathew, "The role of root apoplastic transport barriers in salt tolerance of rice (Oryza sativa L.)," Planta, vol. 230, no. 1, pp. 119-134, 2009.

[21] N. T. T. Hoai, I. S. Shim, K. Kobayashi, and U. Kenji, "Accumulation of some nitrogen compounds in response to salt stress and their relationships with salt tolerance in rice (Oryza sativa L.) seedlings," Plant Growth Regulation, vol. 41, no. 2, pp. 159164, 2003.

[22] M. Djanaguiraman, J. A. Sheeba, A. K. Shanker, D. D. Devi, and U. Bangarusamy, "Rice can acclimate to lethal level of salinity by pretreatment with sublethal level of salinity through osmotic adjustment," Plant and Soil, vol. 284, no. 1-2, pp. 363$373,2006$.

[23] G. B. Gregorio and D. Senadhira, "Genetic analysis of salinity tolerance in rice (Oryza sativa L.)," Theoretical and Applied Genetics, vol. 86, no. 2-3, pp. 333-338, 1993.

[24] L. Zeng and M. C. Shannon, "Salinity effects on seedling growth and yield components of rice," Crop Science, vol. 40, no. 4, pp. 996-1003, 2000.

[25] L. Zeng, M. C. Shannon, and C. M. Grieve, "Evaluation of salt tolerance in rice genotypes by multiple agronomic parameters," Euphytica, vol. 127, no. 2, pp. 235-245, 2002.

[26] M. C. Brundrett, B. Kendrick, and C. A. Peterson, "Efficient lipid staining in plant material with Sudan Red 7B or fluoral yellow 088 in polyethylene glycol-glycerol," Biotechnic and Histochemistry, vol. 66, no. 3, pp. 111-116, 1991.

[27] K. L. Sahrawat, G. Ravi Kumar, and J. K. Rao, "Evaluation of triacid and dry ashing procedures for determining potassium, calcium, magnesium, iron, zinc, manganese, and copper in plant materials," Communications in Soil Science and Plant Analysis, vol. 33, no. 1-2, pp. 95-102, 2002.

[28] M. Orcuttd and E. T. Nilsen, Physiology of Plants Under Stress: Abiotic Factor, John Wiley \& Sons, 2000.

[29] R. Munns, "Comparative physiology of salt and water stress," Plant, Cell and Environment, vol. 25, no. 2, pp. 239-250, 2002.

[30] J. Lynch, V. S. Polito, and A. Lauchli, "Salinity stress increases cytoplasmic Ca activity in maize root protoplasts," Plant Physiology, vol. 90, no. 4, pp. 1271-1274, 1989.

[31] S. Lutts, J. M. Kinet, and J. Bouharmont, "Effects of salt stress on growth, mineral nutrition and proline accumulation in relation to osmotic adjustment in rice (Oryza sativa L.) cultivars differing in salinity resistance," Plant Growth Regulation, vol. 19 , no. 3, pp. 207-218, 1996. 
[32] I. Baxter, P. S. Hosmani, A. Rus et al., "Root suberin forms an extracellular barrier that affects water relations and mineral nutrition in Arabidopsis," PLoS Genetics, vol. 5, no. 5, Article ID e1000492, 2009.

[33] J. L. Zhang, T. J. Flowers, and S. M. Wang, "Mechanisms of sodium uptake by roots of higher plants," Plant and Soil, vol. 326, no. 1, pp. 45-60, 2009. 


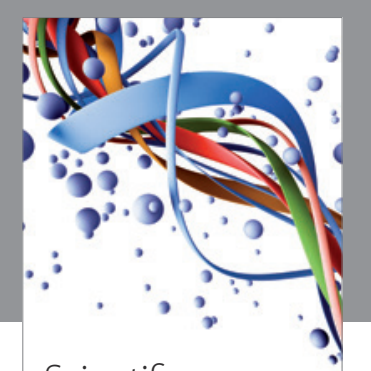

Scientifica
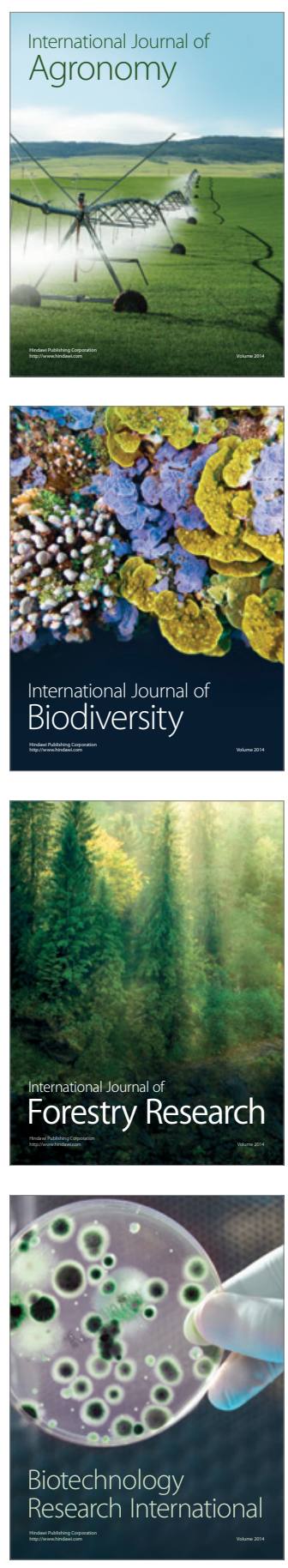
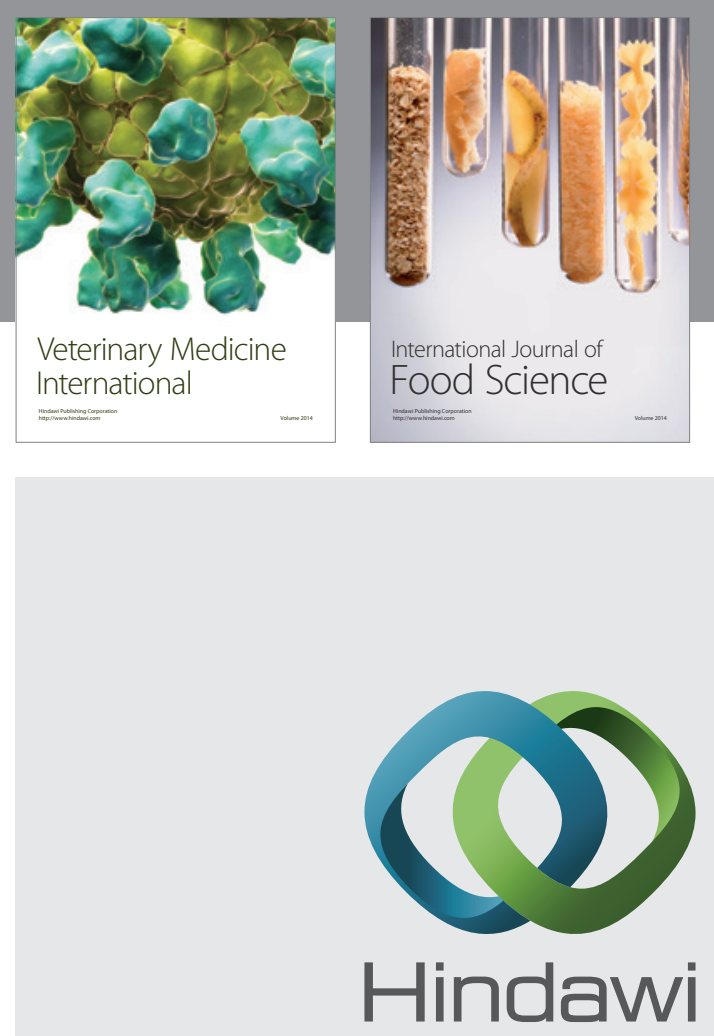

Submit your manuscripts at

http://www.hindawi.com
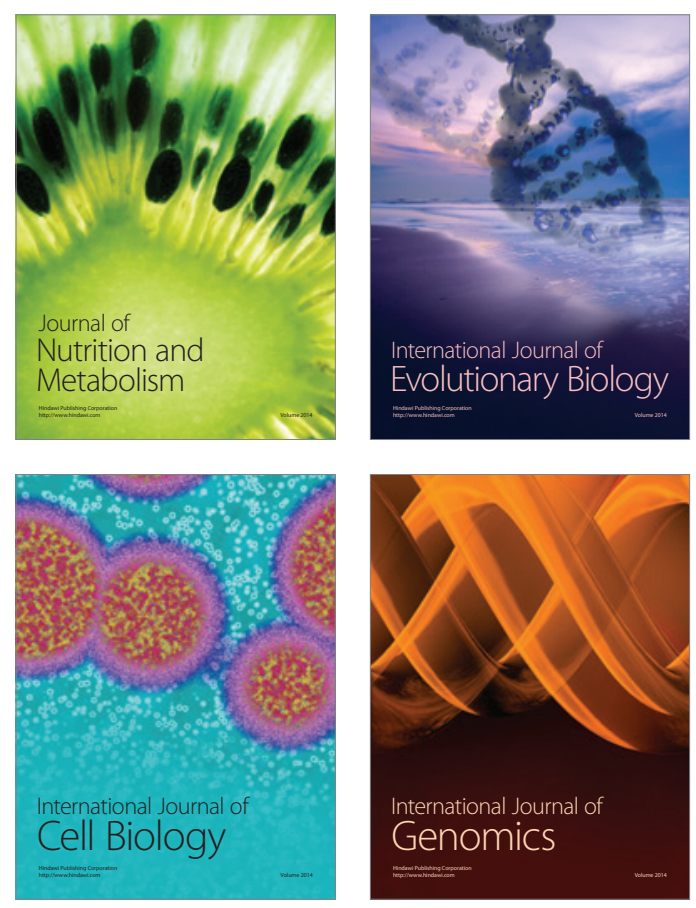
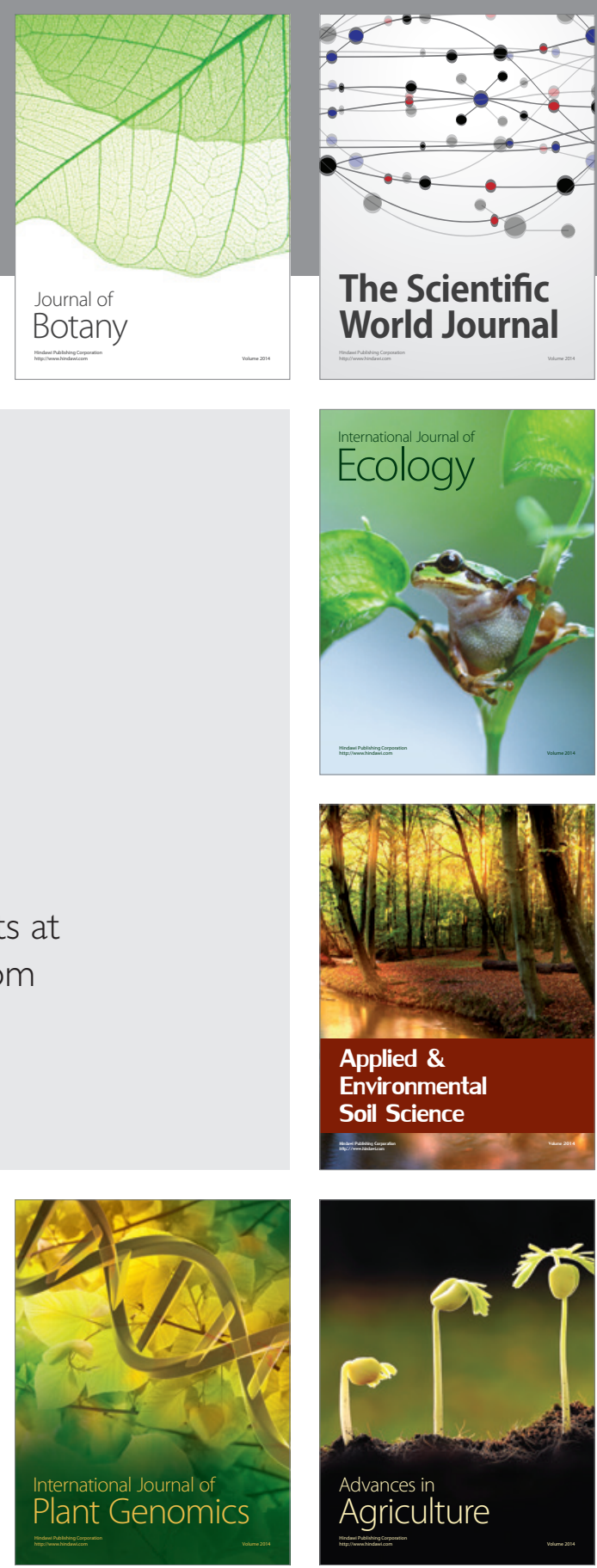

The Scientific World Journal
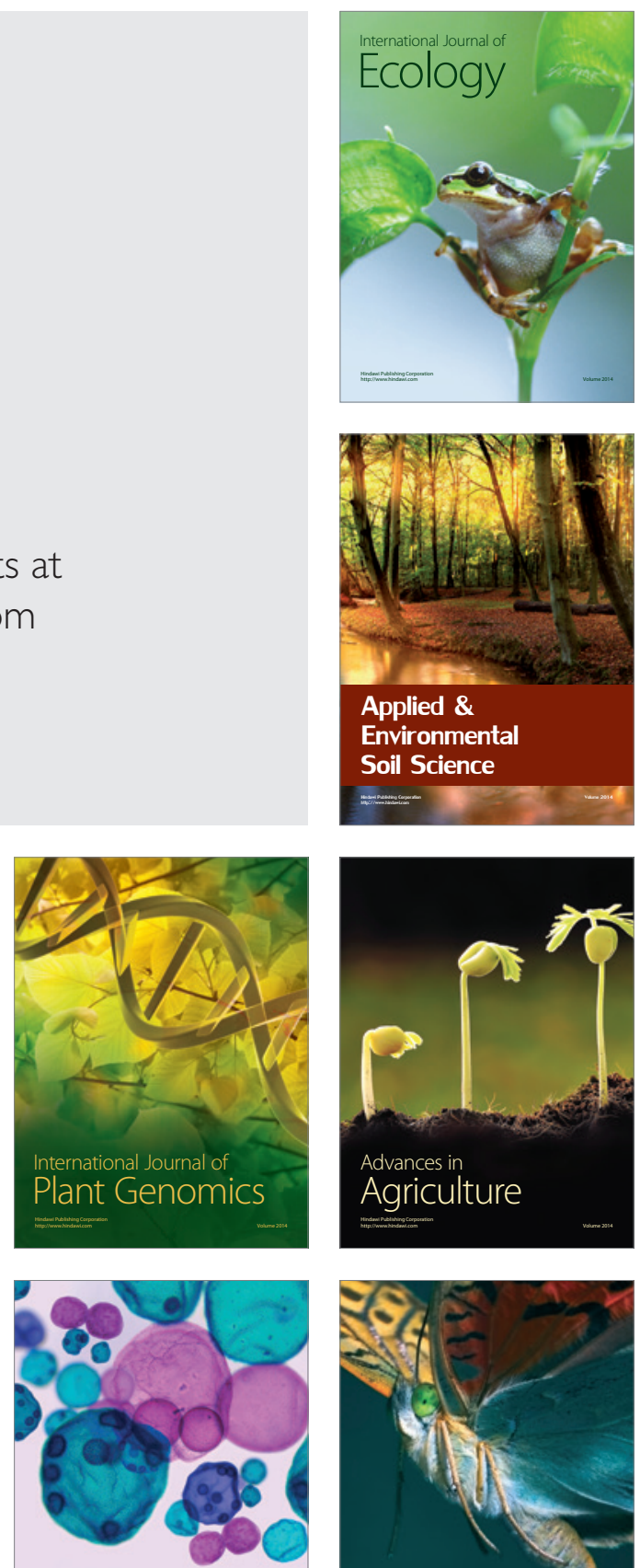

International Journal of Microbiology

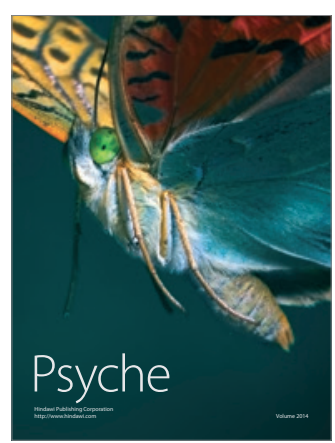

